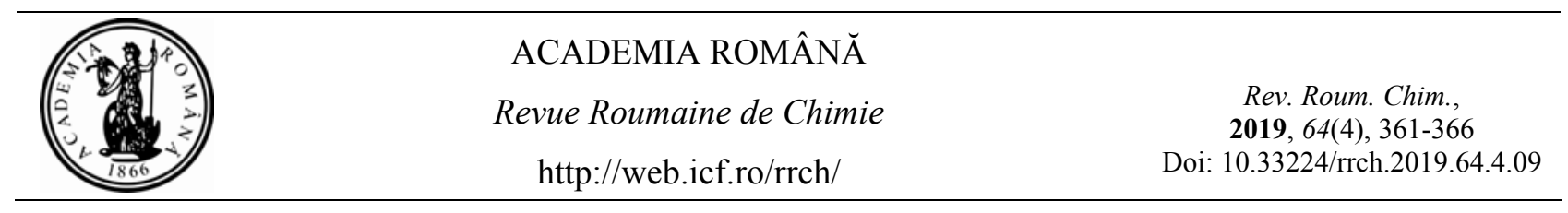

\title{
PHTHALOCYANINES CONTAINING RESORCINARENE CAVITANDS; SYNTHESIS AND HEAVY METAL ION EXTRACTION PROPERTIES
}

\author{
Cihan KANTAR \\ Recep Tayyip Erdogan University, Faculty of Arts and Sciences, Department of Chemistry, Rize, Turkey
}

There are several studies about phthalocyanines containing resorcin[4]arene groups at literature. However, their heavy metal ion extraction properties are unknown. Therefore, the novel phthalocyanines containing tetra and octa resorcin[4]arene cavitands were synthesized and investigated extraction properties for some environmentaly important heavy metal ions. The structures were characterized by elemental analysis, ${ }^{1} \mathrm{H}$ NMR, ${ }^{13} \mathrm{C}$ NMR, UV/vis and FT-IR spectroscopy techniques. The extraction capacities were analyzed through liquid-liquid extraction method. The novel phthalocyanine compounds TP5ZnPc and TP6ZnPc seem to be proper for the removal of heavy metal cations.
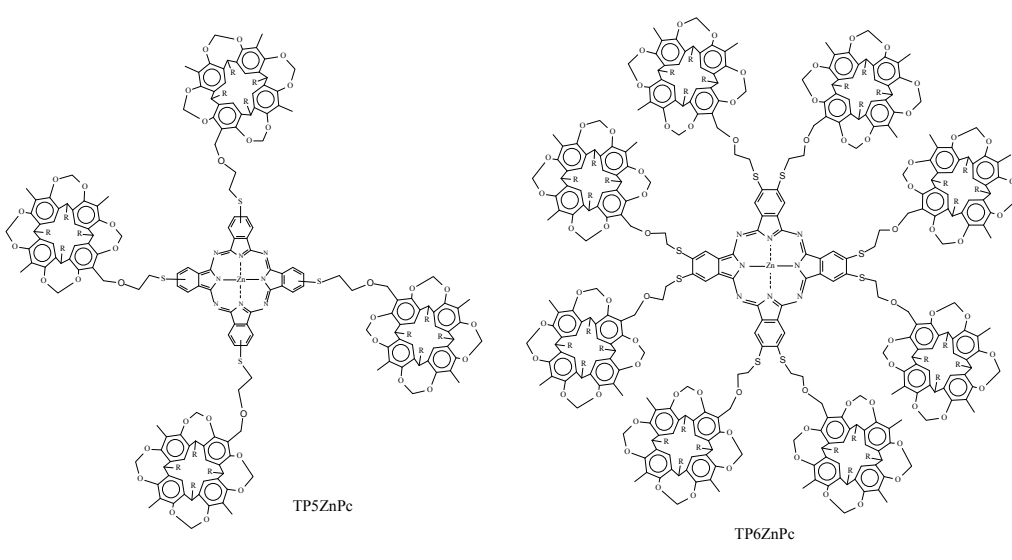

\section{INTRODUCTION}

Resorcin[4]arenes can be prepared in the acidcatalysed condensation reaction between resorcinol derivatives and an aliphatic or aromatic aldehyde. ${ }^{1}$ Resorcin[4]arenes are known to possess hydrophilic (upper rim) and hydrophobic (lower rim) regions and a cavity, which can accommodate small organic molecules and ions. ${ }^{2,3}$ Resorcin[4]arene cavitand therm is mostly used for the bridged form of resorcin[4]arene octols. ${ }^{4}$ Their receptor and ionophore properties have been previously described in literature. ${ }^{5-11}$

The phthalocyanines are synthetic tetrapyrrolic macrocylic compounds which are not naturally occurring. ${ }^{12}$ These compounds are very important industrial pigments that provide stable and strongly chromatic blues and greens. The phthalocyanines have improved photophysical and photochemical properties due to strong absorbance at long wavelengths. ${ }^{13}$ In addition, their novelty is rapidly growing in other fields where they are used as liquid crystals, chemical sensors, semiconductors, functional polymers and molecular metals, among others. $^{14}$

Literature shows that there are few publications about phthalocyanines containing resorcin[4]arene groups. $^{15,16}$ In addition, we have previously reported novel polymeric phthalocyanines carrying resorcin[4] arene units. ${ }^{17,18}$ However, synthesis and heavy metal cation extraction properties of monomeric phthalocyanines containing resorcin[4]arene cavitands have not investigated so far.

Heavy metals are a group of metallic elements that have relatively high density and have toxic

* Corresponding author: cihankantar@hotmail.com 
effect on environment. Toxic heavy metals must be removed from the aqueus environments especially when they exist above their threat level.

This work aims to synthesize novel phthalocyanines containing resorcin[4]arene cavitand and to determine whether suitable for some important heavy metal cations removal from aqueous environments.

\section{EXPERIMENTAL}

Tetra(2-hydroxyethylthio) Zn(II)phthalocyanine (TNZnPc), Octa(2-hydroxyethylthio) Zn(II) phthalocyanine (TKZnPc), Octol-resorcin[4]arene 2, 5, 8, 11, 14, 17, 20, 23-octamethylpentacyclo $\quad\left[19 \cdot 3 \cdot 1 \cdot 1^{3,7} \cdot 1^{9,13} \cdot 1^{15,19}\right]$ octacosa1(25),3(28),4,6,9(27),10, 12,15(26),16,18,21,23-dodecaene-4, 6, 10, 12, 16, 18, 22 ,24octol (TP1) were prepared according to literature procedures. $^{19-21}$ The reagent 2-methyl resorcinol was purchased from Sigma Aldrich Chemical Company. FT-IR spectra were recorded by Perkin-Elmer Spectrum 100 Infrared Spectrometer. UV/vis spectra were recorded by Perkin-Elmer UV/vis spectrometer. ${ }^{1} \mathrm{H}$ NMR and ${ }^{13} \mathrm{C}$ NMR studies were performed by Varian 400 FT-NMR. Elemental analyses were performed by the Instrumental Analyses Laboratory of the Recep Tayyip Erdogan University.

\section{Synthesis}

Bridged resorcin[4] arene $1,7,11,15,21,23,25,28$ Octamethyl-2, $20: 3$, 19-dimetheno $1 \mathrm{H}, 21 \mathrm{H}, 23 \mathrm{H}, 25 \mathrm{H}$, bis[1,3]dioxocino[5,4-i:5', 4'-i']benzo[1,2-d:5,4-d']bis[1,3]benzodioxocin (TP2)

Octol-resorcin[4]arene TP1 (20 g, $33 \mathrm{mmol})$ was dissolved in DMSO $(250 \mathrm{~mL})$ in a round bottomed flask. Cesium carbonate $(100 \mathrm{~g}, 300 \mathrm{mmol})$ was added to this solution and stirred for $1 \mathrm{~h}$. Then dichloromethane (72 g, $55 \mathrm{ml}, 847 \mathrm{mmol}$ ) was added to this mixture at room temperature. The reaction mixture was heated at $80{ }^{\circ} \mathrm{C}$ for 24 $\mathrm{h}$. The reaction mixture was filtered and filtrate was poured into water, and solid material was collected by filtration. The product was purified by column chromatography with $\mathrm{CH}_{2} \mathrm{Cl}_{2}$ as the mobile phase. Mp: $>360{ }^{\circ} \mathrm{C}$, Yield $\% 47,10 \mathrm{~g}$. FT$\mathrm{IR} v_{\max } / \mathrm{cm}^{-1} 2972$ (Aliphatic CH), 2879, 1474 (Aromatic C=C), 1458, 1429, 1303, 1234, 1093, 974, 787. ${ }^{1} \mathrm{H}$ NMR $\left(\right.$ DMSO-d $\left._{6}\right)$ $\delta$, ppm: $7.51(4 \mathrm{H}, \mathrm{s}, \mathrm{ArH}), \quad 5.87-5.86\left(4 \mathrm{H}, \mathrm{d}\right.$, outer of $\left.\mathrm{CH}_{2}\right)$, 4.78-4.76 (4H, q, $\mathrm{CH}), 4.19-4.18\left(4 \mathrm{H}, \mathrm{d}\right.$, inner of $\left.\mathrm{CH}_{2}\right), 1.87$ $\left(12 \mathrm{H}, \mathrm{s}, \mathrm{ArCH}_{3}\right), 1.76-1.75\left(12 \mathrm{H}, \mathrm{d}, \mathrm{CH}_{3}\right) .{ }^{13} \mathrm{C}$ NMR (DMSO$\left.\mathrm{d}_{6}\right) \delta$, ppm: $152.52,139.31,123.99,118.97,98.47,31.65$, $16.44,10.40$.

Monobromo bridged resorcin[4]arene 2,20:3,19Dimetheno-1H,21H,23H,25H-bis [1,3] dioxocino[5,4-i:5', 4'-i']benzo[1,2-d:5,4-d']bis[1,3]benzodioxocin, 7(Bromomethyl)-1,21,23,25-tetramethyl (TP3)

Bridged resorcin[4]arene TP2 (2 g, $3 \mathrm{mmol})$ was dissolved in degassed benzene $(200 \mathrm{~mL})$. Then $\mathrm{N}$ Bromosuccinimide $(0,5 \mathrm{~g}, 3 \mathrm{mmol})$ and (AIBN) 2,2'Azobis(2-methylpropionitrile) $(100 \mathrm{mg}, 0.6 \mathrm{mmol})$ were added to this solution and the reaction mixture refluxed until the yellow color was white. After cooling, the mixture was filtered and the filtrate was evaporated to dryness. The product was purified by column chromatography with $\mathrm{CHCl}_{3}$ as the mobile phase. The intended compound was the third fraction from the column. Mp: $>290{ }^{\circ} \mathrm{C}$, Yield $\% 31,0,7 \mathrm{~g}$. FT-IR $v_{\max } \mathrm{cm}^{-1} 2974$ (Aliphatic CH), 2938, 1472 (Aromatic $\mathrm{C}=\mathrm{C}$ ), 1430, 1300, 1239, 1094, 970, 748. 'H NMR (DMSO$\left.\mathrm{d}_{6}\right) \delta$, ppm: $7.69(1 \mathrm{H}, \mathrm{s}, \mathrm{ArH}), 7.54(3 \mathrm{H}, \mathrm{s}, \mathrm{ArH}), \quad 5.98-5.96$ $(2 \mathrm{H}$, d, outer of $\mathrm{CH} 2), 5.86-5.84\left(2 \mathrm{H}, \mathrm{d}\right.$, outer of $\left.\mathrm{CH}_{2}\right), 4.79$ $4.76(4 \mathrm{H}, \mathrm{q}, \mathrm{CH}), 4.40\left(2 \mathrm{H}, \mathrm{s}, \mathrm{CH}_{2}-\mathrm{Br}\right), 4.27-4.23(4 \mathrm{H}, \mathrm{m}$, inner of $\left.\mathrm{CH}_{2}\right), 1.87\left(9 \mathrm{H}, \mathrm{s}, \mathrm{ArCH}_{3}\right), 1.78-1.75\left(12 \mathrm{H}, \mathrm{m}, \mathrm{CH}_{3}\right)$. ${ }^{13} \mathrm{C}$ NMR (DMSO-d 6 ) $\delta$, ppm: 153.69, 152.73, 152.45, 139.94, 139.71, 139.49, 139.01, 138.67, 124.02, 118.92, 98.97, 98.40, $31.68,24.33,16.40,10.40$.

Preparation of phthalocyanine containing tetra resorcin [4] arene cavitand $(\mathbf{T P 5 Z n P c})$

Tetra(2-hydroxyethylthio) Zn(II)phthalocyanine TNZnPc $(0,2 \mathrm{~g}, 0,22 \mathrm{mmol})$ was dissolved in DMF $(50 \mathrm{~mL})$ in a round bottomed flask. Cesium carbonate $(1 \mathrm{~g}, 3,07 \mathrm{mmol})$ was added to this solution and stirred for $1 \mathrm{~h}$. Then monobromo bridged resorcin[4]arene TP3 (1 g, 1,37 $\mathrm{mmol}$ ) was added to this mixture and reaction mixture was heated at $60{ }^{\circ} \mathrm{C}$ for 3 days. Then reaction mixture was poured into cold ice water and green solid material was collected by filtration. The product was purified by column chromatography with Chloroform/Methanol (100/5) as the mobile phase. Mp: $>200$ ${ }^{\circ} \mathrm{C}$, Yiel \% 64, 0,50 g. FT-IR $v_{\max } \mathrm{cm}^{-1} 2971$ (Aliphatic CH), 2938, 1459 (Aromatic C=C), 1236, 974. ${ }^{1} \mathrm{H}$ NMR (DMSO-d 6 ) $\delta$, ppm: 8.14 (4H, d, ArH), 7.93-7.91 (4H, d, ArH), 7.74-7.73 (4H, d, ArH), 7.63 (4, s, ArH), 7.53 (12H, s, ArH), 5.86-5.81 $\left(16 \mathrm{H}, \mathrm{m}\right.$, outer of $\left.\mathrm{CH}_{2}\right), 4.79-4.77(16 \mathrm{H}, \mathrm{q}, \mathrm{CH}), 4.32-4.30$ $\left(8 \mathrm{H}, \mathrm{d}, \mathrm{Ar}-\mathrm{CH}_{2}-\mathrm{O}\right), 4.22-4.20\left(16 \mathrm{H}, \mathrm{m}\right.$, inner of $\left.\mathrm{CH}_{2}\right), 3.95-$ $3.94\left(8 \mathrm{H}, \mathrm{m}, \mathrm{O}-\mathrm{CH}_{2}\right), 3.59-3.58\left(8 \mathrm{H}, \mathrm{m}, \mathrm{S}-\mathrm{CH}_{2}\right), 1.87-1.75$ $\left(36 \mathrm{H}, \mathrm{d}, \mathrm{ArCH}_{3}\right), 1.77-1.75\left(48 \mathrm{H}, \mathrm{m}, \mathrm{CH}_{3}\right)$. Anal. Calcd. For $\mathrm{C}_{200} \mathrm{H}_{184} \mathrm{~N}_{8} \mathrm{O}_{36} \mathrm{~S}_{4} \mathrm{Zn}: \mathrm{C}, 69.24 ; \mathrm{H}, 5.35 ; \mathrm{N}, 3.23$. Found: C, 69.75; $\mathrm{H}, 5.30 ; \mathrm{N}, 3.05$. UV/Vis $\left(\lambda_{\max } / \mathrm{nm}, \mathrm{CHCl}_{3}\right): 355,623,690$.

Preparation of phthalocyanine containing octa resorcin [4] arene cavitand $(\mathbf{T P 6 Z n P c )}$

Octa(2-hydroxyethylthio) Zn(II) phthalocyanine TKZnPc $(0,2 \mathrm{~g}, 0,16 \mathrm{mmol})$ was dissolved in DMF $(50 \mathrm{~mL})$ in a round bottomed flask. Cesium carbonate $(1,5 \mathrm{~g}, 4,61 \mathrm{mmol})$ was added to this solution and stirred for $1 \mathrm{~h}$. Then monobromo bridged resorcin[4] arene TP3 $(1,1 \mathrm{~g}, 1,51 \mathrm{mmol})$ was added to this mixture and reaction mixture was heated at $60{ }^{\circ} \mathrm{C}$ for 3 days. The reaction mixture was poured into cold ice water and green solid material was collected by filtration. Then product was purified by column chromatography with Chloroform/Methanol (100/5) as the mobile phase. Mp: $>200$ ${ }^{\circ} \mathrm{C}$, Yield $\%$ 74, 0,80 g. FT-IR $v_{\max } \mathrm{cm}^{-1} 2971$ (Aliphatic CH), 1591, 1459 (Aromatic $\mathrm{C}=\mathrm{C}$ ), 1236, 1094, 974. ${ }^{1} \mathrm{H}$ NMR $\left(\mathrm{DMSO}_{-} \mathrm{d}_{6}\right) \delta$, ppm: $7.92(8 \mathrm{H}, \mathrm{s}, \mathrm{ArH}), 7.59-7.55(32 \mathrm{H}, \mathrm{m}$, $\mathrm{ArH}), 6.06-5.91\left(32 \mathrm{H}, \mathrm{m}\right.$, outer of $\left.\mathrm{CH}_{2}\right), 4.81-4.78(32 \mathrm{H}, \mathrm{q}$, $\mathrm{CH}), 4.41\left(16 \mathrm{H}, \mathrm{d}, \mathrm{Ar}-\mathrm{CH}_{2}-\mathrm{O}\right), 4.33-4.01(32 \mathrm{H}, \mathrm{m}$, inner of $\left.\mathrm{CH}_{2}\right), 3.89-3.87$ (16H, m, O-CH $\mathrm{CH}_{2}$, 3.63-3.58 (16H, m, S- $\left.\mathrm{CH}_{2}\right)$, 1.91-1.88 $\left(72 \mathrm{H}, \mathrm{d}, \mathrm{ArCH}_{3}\right), 1.83-1.76\left(96 \mathrm{H}, \mathrm{m}, \mathrm{CH}_{3}\right)$. Anal. Calcd. For $\mathrm{C}_{368} \mathrm{H}_{352} \mathrm{~N}_{8} \mathrm{O}_{72} \mathrm{~S}_{8} \mathrm{Zn}$ : C, 69.49; H, 5.58; N, 1.76 . Found: C, 69.36; H, 5.35; N, 1.65. UV/Vis $\left(\lambda_{\max } / \mathrm{nm}\right.$, $\left.\mathrm{CHCl}_{3}\right): 363,643,706$.

\section{Extraction procedure and measurements}

In order to determine heavy metal cation extraction capacity, picrate extraction methods were performed 
according to Pedersen's procedure ${ }^{22}$. Metal picrate solutions were prepared by successive addition of $1 \times 10^{-2} \mathrm{M}$ metal nitrate solution to $2.5 \times 10^{-5} \mathrm{M}$ aqueous picric acid solution. Equal volume $(10 \mathrm{~mL})$ of aqueous metal picrate solutions $\left(2.5 \times 10^{-5} \mathrm{M}\right)$ and ligand (resorcin[4]arenes and phthalocyanines) solutions $\left(1 \times 10^{-3} \mathrm{M}\right)$ in chloroform were vigorously agitated in a well stoppered glass bottle with a shaker for $1 \mathrm{~h}$. Then remaining metal picrate ions concentration in the aqueous phase was determined spectrophotometrically. Metal picrate cations $\left(\mathrm{Hg}^{2+}, \mathrm{Co}^{2+}\right.$, $\left.\mathrm{Ni}^{2+}, \mathrm{Cu}^{2+}, \mathrm{Cd}^{2+}, \mathrm{Pb}^{2+}\right)$ were measured by UV/vis using maximum wavelength $355 \mathrm{~nm}$. below:

The extractability was calculated by using the equation

$$
\text { Extractability }(\%)=\left[\left(A_{o}-A\right) /\left(A_{o}\right)\right] \times 100
$$

where $A_{o}$ is the absorbance in the absence of ligand. $A$ denotes the absorbance in the aqueous phase after extraction.

\section{RESULT AND DISCUSSION}

\section{Synthesis and Characterization}

The synthetic path of resorcin[4]arene cavitands and novel phthalocyanines containing resorcin[4]arene cavitands can be seen in Schemes 1 and 2. Octol-resorcin[4]arene TP1 was prepared according to literature ${ }^{21}$ but bridged resorcin[4]arene TP2 and monobromo bridged resorcin[4]arene cavitands TP3 were synthesized by modified method from literature. ${ }^{21,23}$ In order to synthesis of bridged resorcin[4]arene TP2 dichloromethane was used as bridging agent. Pure chloroform was used as the mobile phase at the column chromatography of monobromo bridged resorcin[4]arene TP3. Intended compound was the third fraction from the column.

Phthalocyanines containing tetra and octa resorcin[4] arene cavitands (TP5ZnPc and $\mathrm{TP} 6 \mathrm{ZnPc}$ ) were prepared as similar to literature. ${ }^{15}$ The phthalocyanines (TP5ZnPc and TP6ZnPc) were synthesized by reacting of the hydroxylated phthalocyanines (TNZnPc and TKZnPc) with excessive monobromo bridged resorcin[4]arene TP3.

The characterization of the products involved a combination of methods, including FT-IR, UV/vis, ${ }^{1} \mathrm{H}$ NMR, ${ }^{13} \mathrm{C}$ NMR and elemental analysis.

In the FT-IR spectrum, the formation of bridged resorcin[4]arene TP2 was clearly determined by the disappearance of $\mathrm{OH}$ band at $3412 \mathrm{~cm}^{-1}$. The formation of bridged resorcin[4]arene TP2 was signified by the appearance of singlet aromatic peak at $7.51 \mathrm{ppm}$ and outern $\mathrm{CH}$ protons at 5.87$5.86 \mathrm{ppm}$ as a doublet and inner $\mathrm{CH}$ protons at 4.19-4.18 ppm as a doublet, in its ${ }^{1} \mathrm{H}$ NMR spectrum. The ${ }^{13} \mathrm{C}$ NMR spectrum of bridged resorcin[4]arene TP2 showed the presence of bridging carbon atoms at $98.47 \mathrm{ppm}$.

The ${ }^{1} \mathrm{H}$ NMR spectrum of monobromo bridged resorcin[4] arene TP3 confirms single bromation of the bridged resorcin[4] arene TP2. The ${ }^{1} \mathrm{H}$ NMR spectrum of the monobromo bridged resorcin[4]arene TP3 exhibits characteristic signals for the aromatic hydrogens at $7.53 \mathrm{ppm}$ for 3 protons and $7.69 \mathrm{ppm}$ for one proton. The protons of $\mathrm{CH}_{2} \mathrm{Br}$ have been observed at $4.40 \mathrm{ppm}$ as a singlet. ${ }^{13} \mathrm{C}$ NMR spectrum of monobromo bridged resorcin[4] arene TP3 shows the presence of carbon atom of $\mathrm{CH}_{2} \mathrm{Br}$ at $24.33 \mathrm{ppm}$.

The disappearance of the $\mathrm{OH}$ peak at about $3200 \mathrm{~cm}^{-1}$ at FT-IR spectra of the phthalocyanines (TP5ZnPc and TP6ZnPc) clearly signify the nucleophilic coupling of the reagents.

The ${ }^{1} \mathrm{H}$ NMR spectrum of phthalocyanine containing tetra resorcin[4]arene cavitand TP5ZnPc clearly shows characteristic aromatic and aliphatic protons of the phthalocyanine TNZnPc besides protons of compound TP3. The aromatic peaks of phthalocyanine unit are seen at $8.14 \mathrm{ppm}$ as a singlet, at 7.93-7.92 and 7.74-7.73 ppm as two doublets. Aliphatic S-C $\underline{\mathrm{H}}_{2}-\underline{\mathrm{C}}_{2}-\mathrm{O}$ protons of phthalocyanine TP5ZnPc are seen at 3.95-3.94 and 3.59-3.58 ppm as two multiplets.
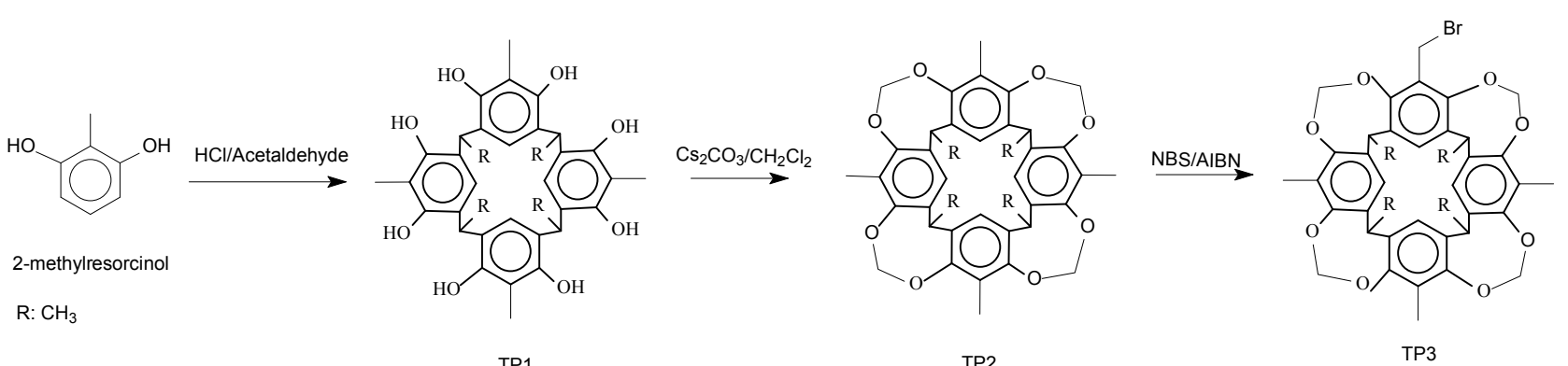

Scheme 1 - Synthesis of resorcin[4]arene cavitands. 

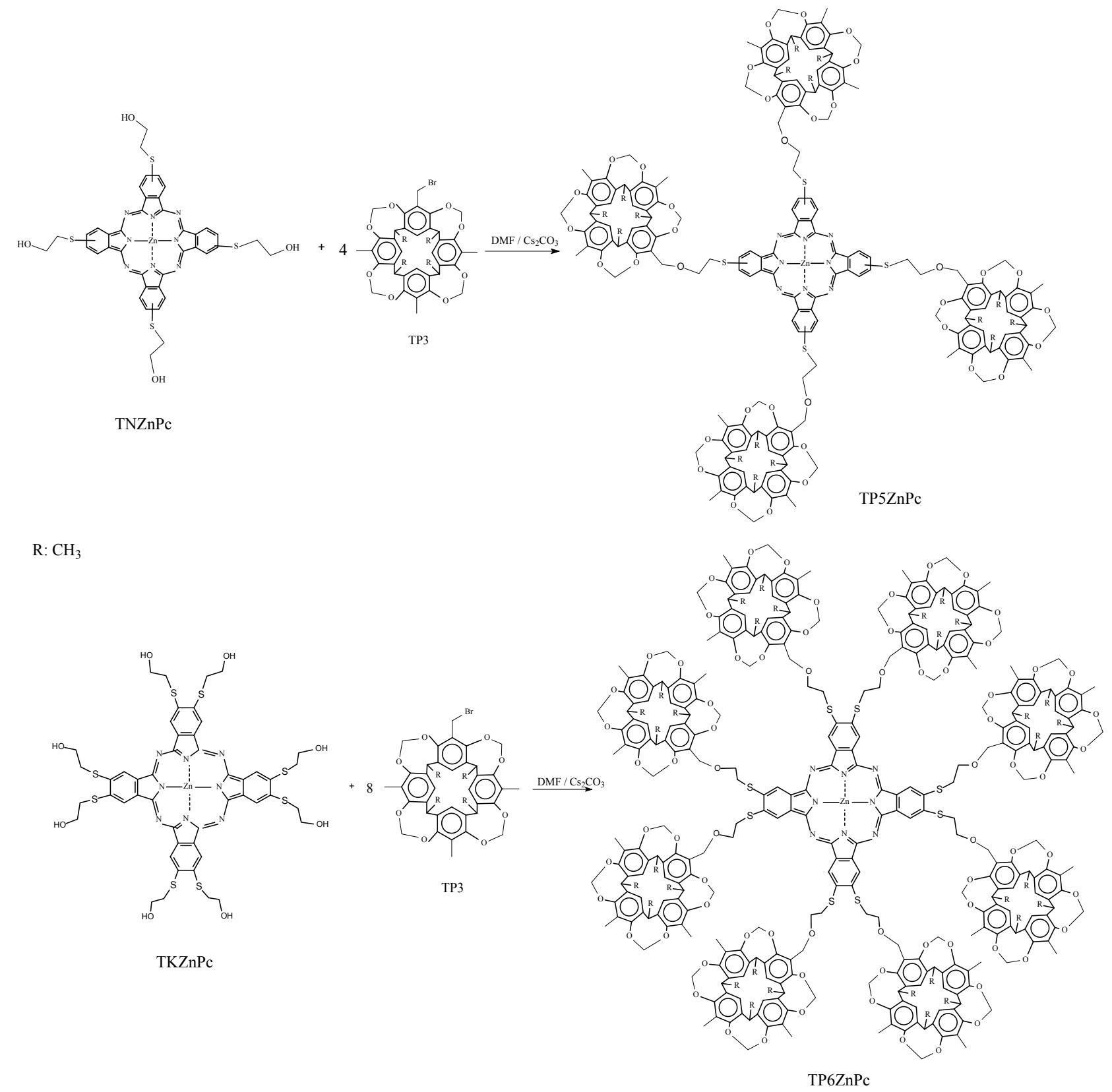

Scheme 2 - Phthalocyanines containing resorcin[4]arene cavitands.

The ${ }^{1} \mathrm{H}$ NMR spectrum of octa resorcin[4]arene cavitand substituted phthalocyanine TP6ZnPc clearly indicated characteristic aromatic and aliphatic protons of the phthalocyanine TNZnPc besides protons of compound TP3. The aromatic peak of phthalocyanine unit are seen at $7.92 \mathrm{ppm}$ as a singlet. Aliphatic S-C $\underline{\mathrm{H}}_{2}-\underline{\mathrm{C}}_{2}-\mathrm{O}$ protons of phthalocyanine TP6ZnPc are seen at 3.89-3.87 and $3.63-3.58 \mathrm{ppm}$ as two multiplets.

Elemental analysis results of the phthalocyanine compounds (TP5ZnPc and TP6ZnPc) show good agreement with the calculated values.

Unlike hydroxylated phthalocyanines, high solubilities of TP5ZnPc and TP6ZnPc in chloroform, practically indicate that accomplished of synthesis of these phthalocyanines compounds.

The best characteristic for the phthalocyanine compounds is their UV/vis spectra in solutions The novel synthesized phthalocyanines TP5ZnPc and $\mathrm{TP} 6 \mathrm{ZnPc}$ showed typical electronic spectra with two strong absorption regions, one of them in UV region between 355 and $363 \mathrm{~nm}$ (B band) and the other in the visible region between 690 and $706 \mathrm{~nm}$ (Q band) in chloroform, respectively. The UV/vis spectra of newly synthesized phthalocyanines TP5ZnPc and TP6ZnPc can be seen in Fig. 1. 


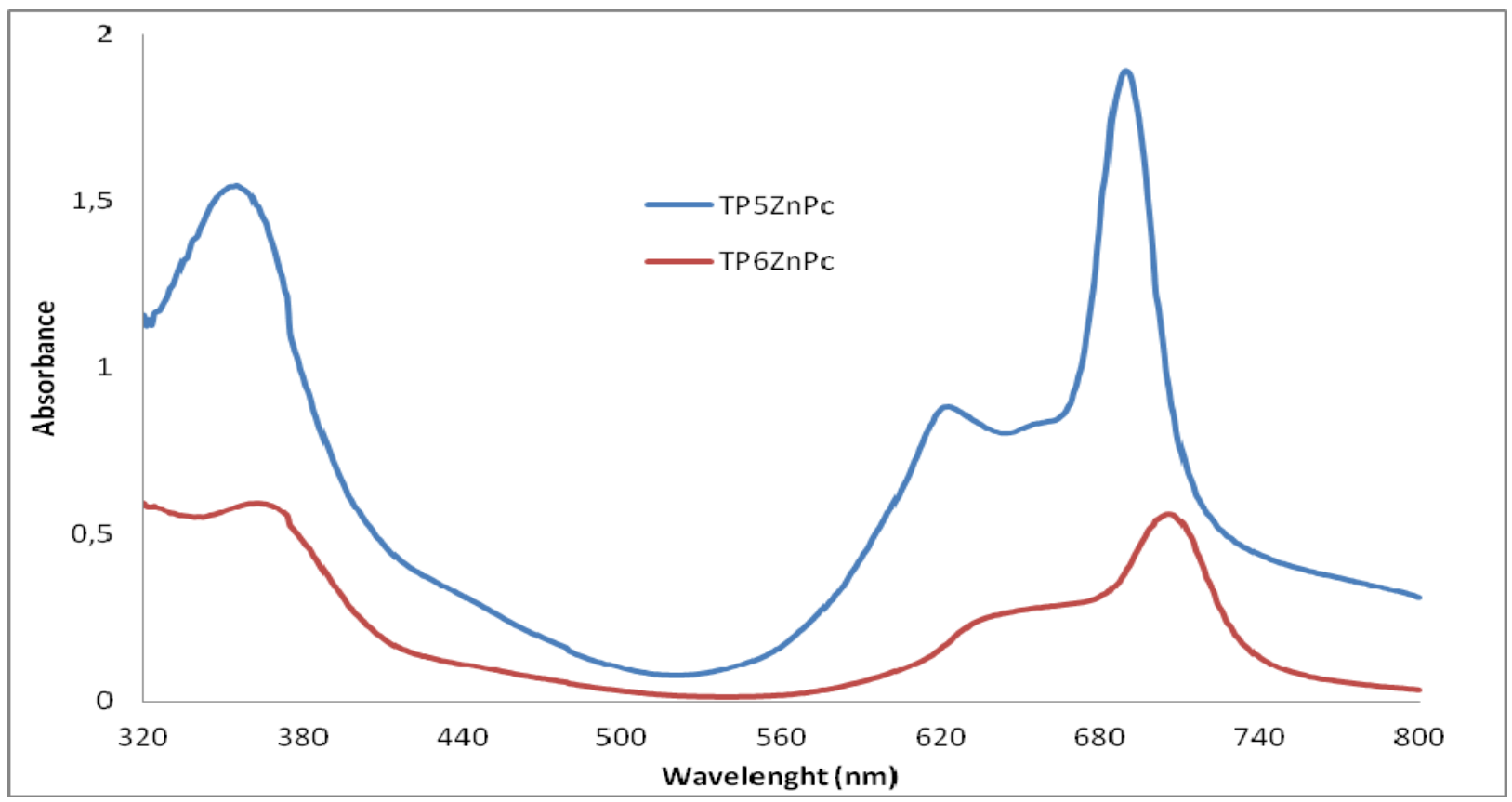

Fig. 1 - UV/vis spectra of phthalocyanines TP5ZnPc and TP6ZnPc in Chloroform.

Table 1

Percent Extraction of Metal Picrates

\begin{tabular}{c|c|c|c|c|c|c}
\hline & \multicolumn{7}{|c}{ Extraction (\%) } & $\mathrm{Hg}^{2+}$ & $\mathrm{Cd}^{2+}$ \\
\hline Compounds & $\mathrm{Co}^{2+}$ & $\mathrm{Ni}^{2+}$ & $\mathrm{Cu}^{2+}$ & $\mathrm{Pb}^{2+}$ & 56 & 0,38 \\
TP2 & 92 & 7,9 & 57 & 78 & 67 & 85 \\
TP3 & 93 & 18 & 62 & 69 & 35 & 96 \\
TP5ZnPc & 94 & 86 & 96 & 96 & 0,22 & 32 \\
TP6ZnPc & 13 & 0,31 & 64 & 0,26 & \\
\hline
\end{tabular}

[Picric acid: $2,5 \times 10^{-5} \mathrm{M}$ ] [Metal Nitrate: $10^{-2} \mathrm{M}$ ] [resocin[4]arenes and phhthalocyanines: $10^{-3} \mathrm{M}$ ] $25{ }^{\circ} \mathrm{C}, 1 \mathrm{~h}, 312 \mathrm{rpm}$ shaking, read at $\lambda=355 \mathrm{~nm}$.

\section{Liquid-Liquid extraction properties}

The extraction properties of resorcin[4]arenes cavitand and phthalocyanines containing these cavitands for metal picrates were tested by liquidliquid extraction and the results are shown in Table 1. In general, bridged resorcin[4]arene TP2 and monobromo bridged resorcin[4]arene TP3 have large affinities for all metal picrates except $\mathrm{Ni}^{2+}$ and $\mathrm{Cd}^{2+}$. Phthalocyanine compound TP5ZnPc showed high affinity for all metal cations at about $\% 90$, except $\mathrm{Hg}^{2+}$. This result indicates compound TP5ZnPc is suitable for the removal of heavy metal cations from aqueous environments. Phthalocyanine compound TP6ZnPc showed large affinity for only $\mathrm{Cu}^{2+}$ about \%64. This feature signifies that compound $\mathrm{TP} 6 \mathrm{ZnPc}$ can use for the selective extraction of $\mathrm{Cu}^{2+}$ from all metal cations media. it's determined that while TP5ZnPc has high affinity almost all metals, TP6ZnPc has large affinity for only $\mathrm{Cu}^{2+}$. Behavior differences between two novel phthalocyanines could be interpreted as compatibility of ionic ratio of $\mathrm{Cu}^{2+}$ with occuring small molecular spaces due to high aggregation tendency of octa substituted phthalocyanine TP6ZnPc.

\section{CONCLUSIONS}

The first time in the literature, novel phthalocyanines containing tetra and octa resocinarene cavitands were synthesized and characterized. Dichloromethane was used as bridging agent at synthesis of bridged resorcin[4]arene and pure chloroform was used as mobile phase at purification of monobromo bridged resorcin[4]arene. Their heavy metal ion extraction properties were investigated by the Pedersen's method. It is determined that novel resorcin[4]arene substituted phthalocyanine compounds can be used in heavy metal cations 
removal investigations, TP5ZnPc for all metals or TP6ZnPc for selectively $\mathrm{Cu}^{2+}$. Moreover, $\mathrm{Cu}^{2+}$ selective compound TP6ZnPc can be used at ion selective electrode and membrane researches.

Acknowledgements: This study was supported by the Scientific and Technological Research Council of Turkey (TUBİTAK, Project no: 215Z438).

\section{REFERENCES}

1. P. Timmerman, W. Verboom and D. N. Reinhoudt, Tetrahedron, 1996, 52, 2663-2704.

2. H. J. Schneider and U. Schneider, J. Inclus. Phenom. Mol., 1994, 19, 67-83.

3. R. Gramage-Doria, D. Armspach and D. Matt, Coord. Chem. Rev., 2013, 257, 776-816.

4. J. R. Moran, S. Karbach and D. J. Cram, J. Am. Chem. Soc., 1982, 104, 5826-5828.

5. S. F. Alshahateet, A. G. Jiries, S. A. Al-Trawneh, A. S. Eldouhaibi and M. M. Al-Mahadeen, Desalin. Water Treat., 2016, 57, 4512-4522.

6. M. M. Garcia, R. T. Cabanas, A. T. Ochoa, A. Toscano and R. Cruz-Almanza, Fullerene Sci. Techn., 2000, 8, 475-482.

7. E. Gaubert, H. Barnier, L. Nicod, A. FavreReguillon, J. Foos, A. Guy, C. Bardot and M. Lemaire, Separ. Sci. Technol., 1997, 32, 2309-2320.

8. L. S. Kuznetsova, A. R. Mustafina, A. Y. Ziganshina, E. K. Kazakova and A. I. Konovalov, J. Incl. Phenom. Macro., 2001, 39, 65-69.
9. A. R. Mustafina, V. V. Skripacheva, L. S. Kuznetsova, S. N. Pod'yachev, E. K. Kazakova and A. I. Konovalov, Russ. J. Coord. Chem+, 1999, 25, 726-728.

10. M. Botta, B. Botta, V. Masignani, F. Corelli and A. Tafi, Spectro. Biol. Molec.: Modern Trends, 1997, 413-414.

11. L. C. Palmer, M. Yamanka, A. Shivanyuk and J. Rebek, Abstr. Pap. Am. Chem. S, 2004, 227, U213-U213.

12. T. W. Hall, S. Greenberg, C. R. Mcarthur, B. Khouw and C. C. Leznoff, Nouv. J. Chim., 1982, 6, 653-658.

13. A. Aktas, M. Piskin, M. Durmus and Z. Biyiklioglu, J. Lumin., 2014, 145, 899-906.

14. M. Harbeck, D..D. Erbahar, I. Gurol, E. Musluoglu, V. Ahsen and Z..Z. Ozturk, Sensor. Actuat. B-Chem., 2011, 155, 298-303.

15. D. Topkaya, F. Dumoulin, V. Ahsen and U. Isci, Dalton $T, \mathbf{2 0 1 4}, 43,2032-2037$.

16. H. Momose, H. Suzuki and M. Kimura, J. Porphyr. Phthalocya., 2014, 18, 843-848.

17. C. Kantar, E. Agar and S. Sasmaz, Dyes Pigments, 2008, 77, 487-492.

18. C. Kantar, E. Agar and S. Sasmaz, Polyhedron, 2009, 28, 3485-3490.

19. I. Ozcesmeci, A.I. Okur and A. Gul, Dyes Pigments, 2007, 75, 761-765.

20. Z. A. Bayir, E. Hamuryudan, A. G. Gurek and O. Bekaroglu, J. Porphyr. Phthalocya., 1997, 1, 349-353.

21. D. J. Cram, S. Karbach, H. E. Kim, C. B. Knobler, E. F. Maverick, J. L. Ericson and R. C. Helgeson, J. Am. Chem. Soc., 1988, 110, 2229-2237.

22. C. J. Pedersen, Cc/Phys. Chem. Earth, 1985, 18-24.

23. T. F. Al-Azemi and M. Vinodh, Tetrahedron, 2011, 67, 2585-2590. 